\title{
CRUDE OIL PRICE, STOCK PRICE AND SOME SELECTED MACROECONOMIC INDICATORS: AN IMPLICATION ON THE GROWTH OF NIGERIAN ECONOMY
}

\author{
Olanitori Idowu Paul ${ }^{1 \mathrm{i}}$, \\ Ademulegun Olaiya Hawley², \\ Adeparubi Olateru Olagbegi ${ }^{3}$ \\ ${ }^{1}$ B.Sc. \\ Paul Consult, Research and Data Analysis, \\ Rufus Giwa Polytechnic, \\ Owo, Ondo State, \\ Nigeria \\ ${ }^{2}$ B.Sc., M.Sc, \\ Faculty of Business Studies, \\ Department of Business Administration and Management, \\ Rufus Giwa Polytechnic, \\ Owo, Ondo State, \\ Nigeria \\ 3B.Sc., M.Sc, \\ Faculty of Business Studies, \\ Accountancy Department, \\ Rufus Giwa Polytechnic, \\ Owo, Ondo State, \\ Nigeria
}

\begin{abstract}
:
Since the first oil price oscillation in 1973s, macroeconomists have viewed sharp measures in the price of oil are generally as an important source of economic vacillations. The goslow of economic activities has important implications for economic agents and markets. Therefore, this paper models and forecasts the crude oil price, stock price and selected macroeconomic variables in Nigeria. A model predicated on the Keynesian model using yearly data between 1986 and 2016 and analysed using VECM and GARCH approaches. The findings showed that there is long run relationship through Vector Error Correction Model which was achieved well in forecasting the selected macroeconomic variables while the volatility in crude oil price and stock price causes by external and internal forces also captured by General Autoregressive Conditional Heteroskadasticity. The long run negative effect of macroeconomic variable on economy growth can be controlled by making strong fiscal and monetary policies. The 2016 recession was reinforced by all
\end{abstract} i Correspondence: email olanitori.idowup@gmail.com, ademulegunolaiya@gmail.com
adeparubia@gmail.com 
share index and exchange rate as the path of growth declined over the forecast horizon. Further checks carried out using normality test validated the choice of this work. The paper concludes that monetary and exchange rate policy consistency are decisive for smoothening business rotation vacillations and promoting market stability.

JEL: L10; E30

Keywords: crude oil price, stock price, gross domestic product, Vector Error Correction Mechanism (VECM), General Autoregressive Conditional Heteroscedasticity (GARCH) and macroeconomic

\section{Introduction}

The provision of reasonable clarification for the oil price, stock price and macroeconomic relationship has occupied the attention of scholars and policymakers over the last four decades. The attention was pinched by the central role which oil and financial sector play in the world economy and the observed linkage between oil price movement, financial sector and business cycle is overemphasized. In recent years, the relationship between oil prices, stock price and macroeconomic variables has been the subject of much investigation and debate. Many studies have used data from developed and emerging countries to demonstrate that oil price shocks are significantly correlated with subsequent economic recession (Hamilton, 2003, 2008; Gisser and Goodwin, 2006; Lounani, 2006; Mork, 2009; Lee et al., 2005; Keane and Prasad, 2006; Rotemberg and Woodford, 2006; Hamilton and Herrera, 2004; Counado and Perez de Garcia, 2005; Gronwald, 2008; Kilian, 2008). A number of studies have also indicated that oil price shocks have a pass-through effect on inflation (Hamilton, 2006; Hooker, 2002; Chen, 2009). Other researchers have posited that inflation stimulated by oil price shocks reduce the real money balance in the economy, leading to recession (Mork, 2009, 2004; Hoover and Perez, 2004). Bernanke et al. (2007) advocated the viewpoint that the economic recession stimulated by dramatic oil price shocks is not caused solely by the influence of oil shocks on the supply side. Due to anti-inflationary tendencies, monetary authorities generally adopt contractionary policy after the impact of oil shocks, and this is a possible reason behind deepening of economic recession.

Since 1970s, macroeconomists have viewed changes in the oil price as an important source of fluctuations, as well as a paradigm of global shock, likely to affect many economies instantaneously. Such a discernment is largely due to the two episodes of low growth, high unemployment and high inflation that characterized most industrialized economies in the mid and late of 1970s (Blanchard and Gali, 2007). Oil price fluctuation not only is one of the most important causes of many crises and economic fluctuation in oil importing countries, as an important input in production function, but also it is for oil exporting countries as a main source of government revenues. According to Hamilton $(2003,2006)$ the most US recessions were preceded by increases in the price of oil, but the 
stability of this relation has been challenged by a number of authors, in particular Hooker (2006) and Blanchard and Gali (2007); They believe that oil shocks effects in recent years are different from 1970s and the dynamic effects of oil shocks have decreased considerably over time for oil importing countries. In oil exporting countries, oil revenue effects on Gross Domestic Production (GDP) as a part of export revenues directly. In addition to this direct effect, it effects on the other parts of GDP's equation, indirectly.

Determining the means to achieve a suitable trade-off between high inflation and high unemployment is a dilemma policymakers must deal with when facing disruptions in the economic system due to oil price shocks. Investigating the dynamics between oil prices and price levels assists authorities to formulate more effective monetary policy. In traditional economic models, fluctuations in oil prices are seen as supply-side shocks. The augmented Phillips Curve framework has often been used in empirical research to estimate the extent of oil price pass-through into CPI inflation (Hooker, 2002; LeBlanc and Chinn, 2004; Chen, 2009; Herrera and Pesavento, 2009). However, most previous studies on the relationship between oil prices and CPI inflation have focused on industrialized countries; few have made emerging countries the subjects of research. Using monthly data and error correction models, this study investigated the short-run and long-run pass-through effects of oil prices on domestic inflation in emerging Asian countries.

A development in the global economy posing a great challenge to policy makers across countries is the increasing spate of fluctuations in oil prices. The price oil oscillating between $\$ 17$ and $\$ 26$ at different times in 2002 hovered around $\$ 53$ per barrel by October 2004. In fact, the price of oil has witnessed profound fluctuations since 1974 . Persistent oil shocks could have severe macroeconomic implications, thus inducing challenges for policy making - fiscal or monetary in both the oil exporting and oil importing countries over the past three decades (Kim and Loughani, 2002; Taton, 2008; Mork, 2004; Hooker, 2006; Caruth, Hooker and Oswald, 2006; Daniel, 2007; Hamilton, 2006; and Cashin et al 2000). Some of these studies suggest rising oil prices reduced output and increased inflation in the 1970s and early 1980s and falling oil prices boosted output and lowered inflation particularly, in the U.S in the mid-to late 1980s. The transmission mechanisms through which oil prices have impact on real economic activity include both supply and demand channels. The supply side effects are related to the fact that crude oil is a basic input to production, and consequently an increase in oil price leads to a rise in production costs that induces firms to lower output. Oil prices changes also entail demand-side effects on consumption and investment. Consumption is affected indirectly through its positive relation with disposable income. Oil price rises reduces the consumers spending power. Investment may also be affected if the oil price shock encourages producers to substitute less energy intensive capital for more energyintensive capital. The magnitude of this effect is in turn stronger the more the shock is perceived to be long-lasting. For this reason, the theoretical literature has been of a general equilibrium nature, with different authors assigning different weights to the supply and demand channels. 
The provision of plausible explanation for the oil price-macroeconomic relationship has occupied the attention of researchers and policymakers over the last four decades. The attention was drawn by the central role which oil plays in the world economy and the observed linkage between oil price movement and business cycle. Oil plays a dominant role in Nigerian economy given its huge contribution to the revenue of the country. For instance, CBN statistical bulletin (2011) shows that oil receipts accounted for $82.1 \%, 83 \%$ and about 90 per cent of the nation's foreign exchange earnings in 1974, 2008 and 2010 respectively.

However, it is empirically established that oil price is one of the most volatile prices which has significant impact on macroeconomic behavior of many developed and developing economies (Ferderer, 2006; Guo \& Kliesen, 2005). Therefore, the dependence of the Nigerian economy on oil proceeds as the major source of revenue is capable of raising suspicion about the impact of oil price volatility on macroeconomic volatility in the country. Macroeconomic volatility implies the vulnerability of macroeconomic variables to tremors. It is the tendency of macroeconomic variables such GDP, inflation, exchange rate, interest rate etc. to be unstable and weak in terms of withstanding shock. It is a situation whereby little shock in the economy subjects the macroeconomic variables to fluctuations and uncertainty. In the light of this, many studies investigated the impact of oil price changes on macroeconomic variables in Nigeria. The consensus finding is that while oil price changes have direct significant relationship with many macroeconomic variables, it does not significantly affect output growth (Wilson, et al; 2014; Taiwo, et al; 2012; Apere \& Ijiomah, 2013). The implications of crude oil price, stock price and macroeconomic indicators has been a subject of many studies on the growth economy. Most of these studies are concerned with the developed economies while few have recently showed concern with the developing country like Nigeria. Hence, this study looked on crude oil price, stock price and some selected macroeconomic indicators that as implication on the growth of Nigeria economy based on the recent trend on Nigeria economy from the angle of global determinant. Following this introduction, Section 2 dwells on reviewing related literature while methodological issues are covered in Section 3. Section 4 presents and discusses the finding. Summary and Conclusion in Section 5.

\section{Literature Review}

\subsection{Clarification of Concepts}

Crude Oil Price: Crude oil prices measure the spot price of various barrels of oil quoted in the global oil market. These oil barrels include West Texas Intermediate (WTI), Brent Blend, OPEC basket price and the New York Mercantile Exchange (NYMEX) futures price among others. The Nigerian crude belongs to the OPEC Basket Price category which is the mean value of prices obtained from Nigeria and other countries like Algeria, Indonesia, Saudi Arabia, Dubai, Venezuela and Mexico. Due to the lower quality of oil from these countries, it commands lower price than both WTI and Brent blend. 
Stock Price: A share price is the price of a single share of a number of saleable stocks of a company, derivative or other financial asset. In layman's terms, the stock price is the highest amount someone is willing to pay for the stock, or the lowest amount that it can be bought for. In economics and financial theory analysts use random walk techniques to model behavior of asset prices, in particular share prices on stock markets, currency exchange rates and commodity prices. This practice has its basis in the presumption that investors act rationally and without biases, and that at any moment they estimate the value of an asset based on future expectations. Under these conditions, all existing information affects the price, which changes only when new information comes out. By definition, new information appears randomly and influences the asset price randomly. Empirical studies have demonstrated that prices do not completely follow random walks. Low serial correlations (around 0.05) exist in the short term, and slightly stronger correlations over the longer term. Their sign and the strength depend on a variety of factors.

Economic Growth: For the purpose of this paper, economic growth refers to an increase in the Gross Domestic Product (GDP) of a country brought about by changes in major macroeconomic variables. The GDP simply measures the market value of final goods and service produced in a country within a year. In this paper, therefore, GDP annual growth rate is used as a proxy for economic growth. It is a measure of the annual percentage growth rate of GDP at market prices based on constant local currency but aggregated on constant 2010 U.S. dollars.

The sudden negative distortions in the price of crude oil in the last and the first quarters of 2014 and 2015 respectively have raised panic in both oil exporting and oil dependent economies. In Nigeria particularly, economic activities and budgeting will be streamlined within the confines of this new oil price. Questions are raised on how to diversify the economy in a way of shifting our focus from oil as our main stay to other sectors like agriculture and manufacturing. Distortions in the international crude oil price affect both exchange rate and inflation rates of an oil dependent economy, this in-turn affect prospects of the economy for investors to invest and its direct consequence is reflected on the inevitability and returns of the stock market and the economy at large.

The degree of relationship among macroeconomic variables, crude oil prices, and asset values have long been topic of dynamic economic research since the United States prompted financial crises in 2008. Stanching from the Lehman Brothers filing for bankruptcy, the sharp oscillation of crude oil prices and volatile punches in the major stock market have caused great concern regarding economic growth in both developed and developing countries. Therefore, the provision of plausible explanations for the relationship between oil price movement and macroeconomic performance has occupied the responsiveness of economists over the last four decades.

According to Hamilton (2003), the bulk of pioneering studies on oil price and macroeconomic interactions were targeted at establishing causal links owing to the fact that the oil price episode was viewed as a permanent event with the attendant effects on recessions in oil dependent economies. First, transmission mechanism through which oil 
price impacts real economic activity includes both supply and demand channels. The supply-side effects are related to the fact that crude oil is a basic input of production, and an increase (decrease) in oil price leads to a rise (fall) in production cost, which induces firms' lower (higher) output. On the demand side, the effect is on consumption closely tied to disposable income and investment which is attached to the firm's cost.

Second, economic theory suggests that stock prices reflect expectations about future firms' earnings. The fundamental value of a firm's stock equals the present value of expected future dividends. Hence, firms' profits are important parts of Gross Domestic Product (GDP), consumption and investment. The nature of stock prices therefore, should be a valuable indicator of economic activities.

The oil boom of the early 1970s had a persuasive effect on the growth \& development of the economy. Oil suddenly accounted for more than 90 percent of export, contributed about 80 percent to total revenue and this substantially affected the scope and content of investment, production and consumption patterns as well as government's policies and programmes. Despite all these, economic problems began to manifest in 1978 and went through 1983/84 when oil prices declined remarkably by 45\%. There was negative growth rate of $6.7 \%$, external current account deficit grew to 6 percent of GDP, fiscal imbalance and high rate of indebtedness emerged. This in a way ushered in the Structural Adjustment Programme (SAP) with currency devalued and worsened inflation to 72 percent in 1995. Between 1997 and 2010, the rate has been moderated remarkably reaching a single digit. However, as at September 2011, the inflation rate stood at 10.3 percent.

Currently, the banking industry is being prudentially restructured to ensure soundness and transparency. The various policies of the Central Bank of Nigeria (CBN) adumbrated in the Federal budget as well as the entire financial system reformation contained therein the intimations and uses of excesses achieved. The global recession that occurred in 2008, 2012 and 2016 have affected subprime lending and traumatized the stock market because the peak had been reached according to the business cycle theory. Therefore, the growing need of the sophisticated stock market is justified and the effect of oil and stock prices on economic activities in Nigeria cannot but be analyzed.

Traditionally, oil prices have been more volatile than many other commodity or asset prices since World War II. The trend of demand and supply in the Global economy coupled with the activities of OPEC consistently affect the price of oil. In this current year, crude oil price oscillates between US $\$ 110 / \mathrm{b}$ and US $\$ 140 / \mathrm{b}$. This rapid increase has become a great concern to academics as well as policy makers because it has not translated to changes in domestic end-user prices of kerosene, gasoline, petrol and diesel neither has it improved the standard of living of Nigerians. Sequentially, the mobilization of resources from national savings and investment for the purpose of economic growth is the central focus of development economists. To further strengthen growth, the stock market promotes efficiency in capital formation and allocation from surplus to deficit areas. 
According to Okereke (2000), provision of equity capital to the market enables companies to avoid over-reliance on debt financing, thus improving corporate debt to equity ratio since deregulation has exposed them to capital market in sourcing cheap and flexible finance. In the same vein, Nyang (1997) pointed out that the financial structure of a firm, that is the mix of debt and equity finances change as the economy develops.

In Nigeria, a few scholars have studied the impact of oil and stock prices on Nigeria economy. For instance, Ayadi et al (2000) examined the effects of oil production shocks on the net oil exporting country using a standard VAR which includes oil production, output real exchange rate and inflation over 1975-1992 period, the impact responses show that a positive oil production shock was followed by rise in output, reduction in inflation and a depreciation of the domestic currency. In a similar study, Olomola and Adejumo (2006) examined the effects of oil price shocks on output, inflation, real exchange rate and money supply in Nigeria within a VAR framework. They found no substantial role of oil price shocks in explaining movements in output and inflation, but on the long run money supply and real exchange rate are significantly affected following a shock to oil prices.

According to the Hotelling's theory on oil price, if non-renewable resources must compete with other assets, there is a systematic way to forecast their future prices. It further proposed that owners of non-renewable resources will only produce a supply of their product if it will yield more than instrument available to them in the market specifically bonds and other interest bearing securities.

The export land model put forward by Dallas Geologist-Jeffrey Brown modelled the decline in oil exports that result when an exporting nation experience both peak in oil production and an increase in domestic oil consumption. He concluded that exports decline at a faster rate than the decline in oil production and also outpaced increase in oil price thereby slowing domestic growth.

Literature examining the impact of oil price changes and macroeconomic volatility continue to gain prominence since 1970s. Hamilton (2003) observed negative relationship between oil price increase and output growth for the period 1948-1972 and state that the correlation between oil price and evolution of economic output was not a mere historical coincidence. Gisser and Goodwin (1986) and Mork (1989), examining the trend of oil price macroeconomy relationship with the inception of Organization of Petroleum Exporting Countries (OPEC) and extending the period to 1988 in order to include the 1986 oil price decline respectively, confirmed Hamilton's findings. Hooker (1996) explored the robustness of oil price-macroeconomy relationship using granger causality test and Vector Autoregressive (VAR) system with structural stability. The result indicates a break down in the relationship and market collapse. He attributed the break down to misspecification of model rather than weaken relationship.

In a trend analysis of crude oil volatility, the Institute for 21st Century Energy (2012) showed the evidence that stable energy prices (including crude oil) would boost GDP growth and the economy would perform better in such situation. Hence, volatile energy price poses a significance jolt to the economy. 
To examine the importance of thresholds on the relationship between oil price shock and economic growth in Nigeria, Adeniyi (2011) applying Multivariate Threshold Autoregressive Model (MTAM) established that oil price shock does not significantly affect movement of macroeconomic aggregates in Nigeria. Olowe (2009) investigated weekly oil price volatility of all countries average spot price using EGARCH $(1,1)$ over the period January 3, 1997 to March 6, 2009. He found that the oil price return series show high persistence of volatility, volatility clustering and asymmetric properties.

Guo and Kliesen (2005) investigated the impact of oil price volatility on macroeconomic activity in U.S. using Granger Causality Test, they found a significant negative impact of oil price volatility on GDP growth over the period 1984 to 2004. Moreover, the study indicates asymmetric effect of oil price volatility on macroeconomic activities.

Examining macroeconomic dynamics in oil exporting countries with the use of Panel VAR, Mohaghegh and Mehrara (2011) established that oil shocks are not necessarily inflationary. Further, domestic policies, instead of oil boom causes inflation and money is the main cause of macroeconomic fluctuations.

Recently, Ebrahim, Inderwidi and King (2014) embarked on theoretical investigation of macroeconomic impact of oil price volatility. The result showed that oil price volatility constitutes a fundamental barrier to economic growth due to its damaging and destabilizing effect on macro economy. Precisely, they show that oil price volatility adversely affects aggregate consumption, investment, industrial production, unemployment and inflation particularly in non-OECD countries.

Wilson, David, Inyiama and Beatrice (2012) examined the relationship between oil price volatility and economic development in Nigeria. Applying Ordinary Least Square and Granger Causality Test, the study shows that there is no significant relationship between oil price volatility and key macroeconomic variables (real GDP, inflation, interest rate and exchange rate).

Contrarily, the study of oil price shocks and volatility of selected macroeconomic indicators in Nigeria carried out by Taiwo, Abayomi and Damilare (2012) using Johasen Cointegration Test and Error Correction Model indicated that crude oil price, stock price and exchange rate have significant influence on the growth of the Nigerian economy. Oriakhi and Osaze (2013) examined the consequences of oil price volatility on the growth of the Nigeria economy within the period 1970 to 2010. With the use of VAR model, the study find that oil price volatility has direct impact on government expenditure, real exchange rate, and real import while real GDP and inflation are indirectly influenced by the oil price volatility. By implication the study shows that changes in oil price determine government expenditure which in turn determines the growth of the Nigerian economy. Similarly, using monthly data, Apere and Ijomah (2013) indicated unidirectional relationship between interest rate, exchange rate and oil price with direction from oil prices. Also, oil price has no significant impact on real GDP. They arrived at this conclusion with the use of EGARCH model, Impulse Response Function and Lag- 
Augmented VAR for the investigation of the macroeconomic impact of oil price levels and volatility in Nigeria during the period 1970-2009.

Over the years, several studies have applied GARCH type models to examine volatility in exchange rates. Elijah and Festus (2008) for example explored the impact of exchange rate volatility on private investment and confirms an adverse effect. Mordi (2006) employing GARCH model argued that failure to properly manage exchange rates can induce distortions in consumption and production patterns and that excessive currency volatility creates risks with destabilizing effects on the economy. Elijah and Festus (2008) examine the effect of exchange rate volatility and inflation uncertainty on foreign direct investment in Nigeria from 1970 to 2005. Adopting GARCH model, the study shows that exchange rate volatility and inflation uncertainty negatively affect foreign direct investment during the period.

Similarly, Azeez, Kolapo, and Ajayi (2012) examined the effect of exchange rate volatility on macroeconomic performance in Nigeria from 1980 to 2010 employing OLS and co-integration techniques. The findings of the study revealed that oil revenue and exchange rate are positively related to GDP while balance of payment is negatively related to GDP. Also, oil revenue and balance of payment exert negative effect while exchange rate volatility has positive effect on the economy.

Despite the identified importance of oil price on the macroeconomic activities, no study has incorporated oil price volatility in the modelling of macroeconomic volatility in Nigeria. Also, interest rate volatility is ignored in the modelling of volatility in Nigeria while few studies on exchange rate volatility use monthly data instead of daily data used in this paper. Likewise, the evaluation of volatility models (ARCH and GARCH models) in the examination of the volatility of GDP growth rate has not received the required attention from researchers. This paper, therefore, fills the research gap by modelling the volatility of major macroeconomic variables (Real GDP, exchange rate and interest rate) incorporating the effect of oil price volatility with the use of ARCH and GARCH models with the use of high frequency data (particularly for exchange rate).

\section{Methodological Consideration}

\subsection{Analytical Foundation}

There are links between crude oil price, stock price and macroeconomic indicators. The empirical analysis is predicated mainly on the neoclassical theory of economic growth. According to the traditional neoclassical growth theory, output growth result from one or more of three factors; increase in labour quantity and quality (through population growth and education); increase in capital (through savings and investment); and improvement in technology (Todaro and Smith, 2006). Using the Solow-Swan exogenous growth model, the Solow neoclassical growth model for which Robert Solow of the Massachusetts Institute of Technology received the Nobel Prize, is probably the bestknown model of economic growth (Todaro and Smith, 2006). Although in some respects Solow's model describes a developed economy better than a developing one, it remains 
a basic reference point for study on growth and development. The basic Solow model describes a closed economy, which allow for substitution between capital and labour. In the process, it assumes that there are diminishing returns to the use of these inputs. The aggregate production function; $\mathrm{Y}=\mathrm{f}(\mathrm{K}, \mathrm{L})$. It is assumed to be characterized by constant returns return to scale. For example, in the special case known as the Cobb Douglas production function, at any time $\mathrm{t}$ we have;

$Y_{t}=K_{t}^{\alpha}\left[A_{t} L_{t}\right]^{\beta}$

Where $\mathrm{Y}$ is the gross domestic product, $\mathrm{K}$ is the capital, $\mathrm{L}$ is labour and $\mathrm{A}(\mathrm{t})$ represents the productivity of labour, which grows over time at an exogenous rate, $\alpha$ is the elasticity of output with respect to capital and $\beta$ is the elasticity of output with respect to labour. Because of constant returns to scale (that is $\alpha+\beta=1$ ) if all inputs are increased by the by the same amount, say $20 \%$, then output will increase by same amount ( $20 \%$ in this case). More generally; $\lambda \mathrm{Y}=\mathrm{f}(\lambda \mathrm{K}, \lambda \mathrm{L})$ where $\lambda$ is some positive amount (1.2 in the case of a $20 \%$ increase) because $\lambda$ can be any positive real number, a mathematical means useful in analyzing the implication of the model is to set $\lambda=1 / \mathrm{L}$ so that: $\mathrm{Y} / \mathrm{L}=\mathrm{f}(\mathrm{K} / \mathrm{L}, 1)$ or $\mathrm{Y}=$ $\mathrm{f}(\mathrm{k})$ Note that the symbol $\mathrm{k}$ is used for $\mathrm{K} / \mathrm{L}$ and not $\mathrm{K} / \mathrm{Y}$ as was used in the AK or HarrodDomar model. This simplification allows us to deal with just one argument in the production function for example, in the Cobb-Douglas case of equation

$\mathrm{Y}=\mathrm{Ak}^{\alpha}$

Where $y$ is the output per worker and $\mathrm{k}$ is capital per worker and equation (2) states that output per worker is a function that depends on the amount of capital per worker. The more capital with which each worker has to work, the more the output that worker can produce. As previously noted, capital accumulation and technological progress are spillover (by-products) of industrialization. Say the labour force grows at rate $\mathrm{n}$, per year and labour. Productivity grows, the rate at which the value of A in the production function increase, at rate $\varnothing$. Solow also described in the equation that;

$\Delta k=\operatorname{sf}(k)-(\delta+n) k$

The growth of capital-labour ratio, $\mathrm{k}$ (known as capital deepening), and shows that the growth of $\mathrm{k}$ depends on savings, $\mathrm{sf}(\mathrm{k})$, after allowing for the amount of capital required to service depreciation, $\delta \mathrm{k}$, and after widening, that is, providing the existing amount of capital per worker to net new worker joining the labour force, nk.

Essentially, from equation

$\mathrm{Y}(\mathrm{t})=\mathrm{K}(\mathrm{t})^{\alpha}[\mathrm{A}(\mathrm{t}) \mathrm{L}(\mathrm{t})]^{\beta}$

the growth rate of $Y$ can be estimated as; 
$\mathrm{Ry}=\mathrm{Ra}+\alpha \mathrm{Rk}+\beta \mathrm{Rl}$

Where Ry is the growth rate of gross domestic product, Ra is rate of growth of factor productivity, which is assumed to be exogenous, Rk is the growth rate of capital stock and $\mathrm{Rl}$ is the rate of growth in labour. Under the assumption that total factor productivity grows at the average rate of $\varnothing$, then equation $\mathrm{Ry}=\mathrm{Ra}+\alpha \mathrm{Rk}+\beta \mathrm{Rl}$ could be rewritten as;

$\mathrm{Ry}=\varnothing+\alpha \mathrm{Rk}+\beta \mathrm{Rl}$

Equation (4) shows that the rate of growth of output is weighted average of the growth rates of factor inputs plus the rate of growth of total factor productivity. ( $\varnothing$ is sometimes referred to as Solow residual, since $\varnothing=\mathrm{Ry}-\alpha \mathrm{Rk}-\beta \mathrm{Rl}$, (Iyoha, 2001).

\subsection{The Model and Estimation Procedure}

The new Keynesian model is used to guide the choice of variables. This line of reasoning is pursued in line with the RBC where economic cycles are driven by internal and external perturbations based on the IS-LM framework within an open economy. This is applicable to the case of Nigeria in view of the country's integration with the rest of the world through the trade, finance and investment channels in addition to its vulnerability to external shocks through the exchange rate pass-through channel. Thus, the multivariate model for Nigeria accounts for the real gross domestic product (RGDP), unemployment rate (UNEP), exchange rate (EXR), interest rate (INTR),crude oil price (COILP) and all share index (ASI). A detailed description of the data used is presented below.

Real Gross Domestic Product (RGDP) is proxy with the real GDP value for the year of analysis, unemployment Rate (UNEM) is proxy with the percentage value of Nigeria unemployment rate, exchange Rate (EXR) and Interest Rate (INTR) are capture with percentage value in the statistical bulletin for the years of analysis, Crude Oil Price (COILP) is extracted based on the oil price benchmark in relation with exchange rate fluctuation for the year period and All Share Index (ASI) is captured from stock exchange market based on the traded share for the period analysis.

Based on the nature of this research work, the work used Vector Autoregressive Mechanism (VECM) System to capture the effect of over parameterized of macroeconomic variables for the long run relationship, while General Autoregressive Conditional Heteroscedasticity (GARCH) was used to fixed the challenges of fluctuation of oil price in the global market. Before the technique can be applied all the variables must be stationary of first differences I(I), that is, unit root test must be conducted to test for stationary of all the variables in the same order and Cointegration test will be done also. The vector error correction (VEC) model is just a special case of the VAR for variables that are stationary in their differences (i.e., I(1)). The VEC can also take into account any co-integrating relationships among the variables. Consider two time-series variables, $\mathrm{yt}_{\mathrm{t}}$ and $\mathrm{x}_{\mathrm{t}}$. Generalizing the discussion about dynamic relationships to these two interrelated variables yields a system of equations: 
$\mathrm{y}_{\mathrm{t}}=\beta_{10}+\beta_{11 \mathrm{y}_{\mathrm{t}-1}+\beta_{12} \mathrm{X}_{\mathrm{t}-1}+\mathrm{Vt}_{\mathrm{t}}^{\mathrm{y}}}$

$\mathrm{x}_{\mathrm{t}}=\beta_{20}+\beta_{21} \mathrm{yt}_{\mathrm{t}-1}+\beta_{22} \mathrm{X}_{\mathrm{t}-1}+\mathrm{Vt}_{\mathrm{t}}^{\mathrm{x}}$

The restructuring of the model above brings about the VECM model. The model is specified as follows;

RGDP= $\mathrm{f}(\mathrm{UNEM}, \mathrm{EXR}, \mathrm{INTR}, \mathrm{COILP}, \mathrm{ASI})$

RGDPt $=\beta_{0}+\beta_{1} \mathrm{UNEM}+\beta_{2} \mathrm{EXR}+\beta_{3} \mathrm{INTR}+\beta_{4} \mathrm{COILP}+\beta_{5} \mathrm{ASI}+\mathrm{U}_{\mathrm{t}}$

The Vector Error Correction Mechanism System is structure below to prove the long run and short run relationship of the model;

$\operatorname{RGDP}_{\mathrm{t}-1}=\beta_{0}+\beta_{1} \mathrm{UNEM}_{\mathrm{t}-1}+\beta_{2} \mathrm{EXR}_{\mathrm{t}-1}+\beta_{3}$ INTR $_{\mathrm{t}-1}+\beta_{4} \operatorname{COILP}_{\mathrm{t}-1}+\beta_{5} \mathrm{ASI}_{\mathrm{t}-1}+\mathrm{U}_{\mathrm{t}}$

Table 1: Unit Root Test (Stationary)

\begin{tabular}{|l|c|c|c|c|c|}
\hline \multirow{2}{*}{ Variables } & \multicolumn{4}{|c|}{ Augmented Dickey Fuller Unit Root Test } & \multirow{2}{*}{$\begin{array}{c}\text { Level of } \\
\text { Integration }\end{array}$} \\
\cline { 2 - 5 } & ADF-Test & $\mathbf{5 \%}$ C.V & ADF-Test & $\mathbf{5 \% ~ C . V ~}$ & $\mathrm{I}$ (I) \\
\hline RGDP & -0.162161 & -2.67767 & -4.903720 & -3.574244 & $\mathrm{I}(\mathrm{I})$ \\
\hline UNEM & -3.395718 & -3.574244 & -4.309824 & -2.998455 & $\mathrm{I}(\mathrm{I})$ \\
\hline EXR & -1.935526 & -3.568379 & -5.186533 & -3.574244 & $\mathrm{I}(\mathrm{I})$ \\
\hline INTR & -4.279640 & -3.568379 & -6.141761 & -3.520787 & $\mathrm{I}(\mathrm{I})$ \\
\hline COILP & -2.555410 & -3.587527 & -4.309824 & -2.735640 & $\mathrm{I}(\mathrm{I})$ \\
\hline ASI & -3.326068 & -3.568379 & -6.065974 & -3.574244 & \\
\hline
\end{tabular}

Source: Eview 9

The result shown in table 1, examine the statistical properties of all the variables for invariant of time trend. The ADF test for unit root was conducted for the variables in the model. The results of the test at level and first difference are presented above. The null hypothesis $\left(\mathrm{H}_{0}\right)$ state that there is unit root in each of the series, that is each variable is non-stationary and variant of the time. The rule of thumb state that the null hypothesis $\left(\mathrm{H}_{0}\right)$ should be accepted if the ADF statistics is less than critical values at any level of significance (i.e. $1 \%, 5 \%$ and $10 \%$ ) and reject if otherwise. The ADF result in the table above indicate that all the variables (i.e. gross domestic product growth (GDPGR), unemployment rate (UNEM), exchange rate (REXR) interest rate (INTR), crude oil price (COILP) and all share indices (ASI) are all stationary at first difference, that is, they are all invariant of the time in trend and at level I(I). Based on the ADF statistical test for unit root (i.e. stationarity, the condition for Johansen Cointegration test for long run relationship has been met and fulfilled (i.e. all the variables must be stationary and integrated of the same order) (Granger, 1986; Engle and Granger, 1987). In view of this, Johansen Cointegration test can now be conducted for both short run and long run relationship of the variables. 


\begin{tabular}{|l|c|c|c|c|c|c|c|}
\hline \multicolumn{7}{l}{ Table 2: Johansen Co-Integration Test } \\
\hline $\begin{array}{l}\text { Null } \\
\text { Hypothesis }\end{array}$ & $\begin{array}{c}\text { Eigen } \\
\text { Value }\end{array}$ & Trace Stat & $\mathbf{0 . 0 5 \% \text { C.V }}$ & Prob; & $\begin{array}{c}\text { Max-Eigen } \\
\text { Value }\end{array}$ & $\mathbf{0 . 0 5 \% \text { C.V }}$ & Prob; \\
\hline $\mathrm{r}=0$ & 0.805945 & 141.6576 & 95.75366 & 0.0000 & 47.54885 & 40.07757 & 0.0060 \\
\hline $\mathrm{r} \leq 1$ & 0.674149 & 94.10875 & 69.81889 & 0.0002 & 32.51815 & 33.87687 & 0.0719 \\
\hline $\mathrm{r} \leq 2$ & 0.574811 & 61.59060 & 47.85613 & 0.0016 & 24.80141 & 27.58434 & 0.1091 \\
\hline $\mathrm{r} \leq 3$ & 0.512448 & 36.78918 & 29.79707 & 0.0066 & 20.83237 & 21.13164 & 1.0550 \\
\hline $\mathrm{r} \leq 4$ & 0.386595 & 15.95681 & 15.49471 & 0.0426 & 14.17321 & 14.26460 & 0.0517 \\
\hline $\mathrm{r} \leq 5$ & 0.059650 & 1.783605 & 3.841466 & 0.1817 & 1.783605 & 3.841466 & 0.1817 \\
\hline
\end{tabular}

In Table 2 above, the Johansen Cointegration test result was presented. The result showed that both the trace statistic and maximum eigenvalue statistic confirm the existence of cointegrating equations among the variables of interest. From the results, the trace statistics indicate that at least five co-integrating vectors occurred and also, that of Max. Eigen shows co-integrating vector by null hypothesis (H0) at $0.05(5 \%)$ level of significant, therefore, the null hypothesis ( $\mathrm{H} 0)$ of not Co-integrating Vector existence should be rejected and accept alternative hypothesis $\left(\mathrm{H}_{1}\right)$ of Co-integrating Vector among variables. This confirmed that there exists a long run equilibrium relationship among the variables in the analysis. Since the variables are co-integrated, this satisfies the convergence property for long run relationship. Therefore, Vector Error Correction Mechanism (VECM) is used to capture the effect of parameterized model or residual for the long run and short run convergence into equilibrium relationship between endogenous/dependent variable and the exogenous/explanatory variables, since more than one Co-integrating vector exists, VECM was the most appropriate econometrics technique to be used since each of underlying variables stands as a single long run relationship equation.

$\mathrm{D}($ RGDP $)=\mathrm{C}(1) *(\mathrm{RGDP}(-1)-118.943895132 * \mathrm{UNEM}(-1)-2.34478207295$

${ }^{*} \operatorname{EXTR}(-1)+7.15120292421 * \operatorname{INTR}(-1)+1.5192708859 * \operatorname{COILP}(-1)-$

$\left.0.00409063932438^{*} \mathrm{ASI}(-1)+114.978237981\right)+\mathrm{C}(2)^{*} \mathrm{D}(\mathrm{RGDP}(-1))+$

$\mathrm{C}(3)^{*} \mathrm{D}(\mathrm{RGDP}(-2))+\mathrm{C}(4)^{*} \mathrm{D}(\mathrm{UNEM}(-1))+\mathrm{C}(5)^{*} \mathrm{D}(\mathrm{UNEM}(-2))+\mathrm{C}(6)$

${ }^{*} \mathrm{D}(\operatorname{EXTR}(-1))+\mathrm{C}(7)^{*} \mathrm{D}(\operatorname{EXTR}(-2))+\mathrm{C}(8)^{*} \mathrm{D}(\operatorname{INTR}(-1))+\mathrm{C}(9)^{*} \mathrm{D}(\mathrm{INTR}($

$-2))+\mathrm{C}(10)^{*} \mathrm{D}(\mathrm{COILP}(-1))+\mathrm{C}(11)^{*} \mathrm{D}(\mathrm{COILP}(-2))+\mathrm{C}(12)^{*} \mathrm{D}(\mathrm{ASI}(-1))+$

$\mathrm{C}(13)^{*} \mathrm{D}(\mathrm{ASI}(-2))+\mathrm{C}(14)$

Table 3: Vector Error Correction Mechanism (VECM) Model for Long Run and Short Run

\begin{tabular}{|l|c|c|c|c|}
\hline Variables & Coefficient & Std. Error & t-Statistic & Prob. \\
\hline Co-integ C(1) & -0.122613 & 0.039780 & -3.082298 & 0.0081 \\
\hline$C(2)$ & 0.201778 & 0.218758 & 0.922377 & 0.3720 \\
\hline$C(3)$ & 0.338955 & 0.177147 & 1.913404 & 0.0764 \\
\hline$C(4)$ & -2.174228 & 3.601174 & -0.603755 & 0.5557 \\
\hline$C(5)$ & -7.134907 & 4.699073 & -1.518365 & 0.1512 \\
\hline$C(6)$ & -0.082336 & 0.101607 & -0.810333 & 0.4313 \\
\hline$C(7)$ & 0.141632 & 0.174454 & 0.811863 & 0.4305 \\
\hline$C(8)$ & 0.877837 & 0.535303 & 1.639888 & 0.1233 \\
\hline
\end{tabular}


Olanitori Idowu Paul, Ademulegun Olaiya Hawley, Adeparubi Olateru Olagbegi CRUDE OIL PRICE, STOCK PRICE AND SOME SELECTED MACROECONOMIC

INDICATORS: AN IMPLICATION ON THE GROWTH OF NIGERIAN ECONOMY

\begin{tabular}{|l|c|c|c|c|}
\hline $\mathrm{C}(9)$ & -0.046767 & 0.544656 & -0.085865 & 0.9328 \\
\hline $\mathrm{C}(10)$ & 0.298573 & 0.289499 & 1.031343 & 0.3199 \\
\hline $\mathrm{C}(11)$ & -0.103629 & 0.292093 & -0.354780 & 0.7280 \\
\hline $\mathrm{C}(12)$ & -0.000337 & 0.000299 & -1.127717 & 0.2784 \\
\hline $\mathrm{C}(13)$ & $5.44 \mathrm{E}-05$ & 0.000345 & 0.157402 & 0.8772 \\
\hline $\mathrm{C}(14)$ & 12.20207 & 4.570062 & 2.670000 & 0.0183 \\
\hline R-squared & 0.832453 & Mean dependent var & 25.78714 \\
\hline Adjusted R-squared & 0.676874 & S.D. dependent var & 18.48080 \\
\hline S.E. of regression & 10.50526 & Akaike info criterion & 7.848483 \\
\hline Sum squared resid & 1545.048 & Schwarz criterion & 8.514585 \\
\hline Log likelihood & -95.87876 & Hannan-Quinn criter. & 8.052117 \\
\hline F-statistic & 5.350667 & Durbin-Watson stat & 2.031440 \\
\hline Prob(F-statistic) & 0.001838 & & \\
\hline
\end{tabular}

Source: Eview 9

The $\mathrm{C}_{1}$ is the co-integrating coefficient that showed long run relationship between the real gross domestic product and all selected macroeconomic indicators variables in the analysis, while $C_{2}$ to $C_{13}$ were used to capture the impact of short run in the model. $C_{2}$ and $\mathrm{C}_{3}$ showed the short run Real GDP period lag on Real GDP, $\mathrm{C}_{4}$ and $\mathrm{C}_{5}$ captured short run unemployment effect on Real GDP, $\mathrm{C}_{6}$ and $\mathrm{C}_{7}$ described the short run impact of exchange rate on Real GDP, $\mathrm{C}_{8}$ and $\mathrm{C}_{9}$ reflect interest rate effect on Real GDP in the short run, while $C_{10}$ and $C_{11}$ showed the short run implication of oil price on Real GDP and lastly, $C_{12}$ and $\mathrm{C}_{13}$ confirm the short run effect of all share indices on Real GDP. All these short run tested were done with Wald test. $C_{2}$ and $C_{3}$ Wald test value was 0.0055 which was less than 0.05 level of significant, therefore one period lag of Real GDP as significant impact on present and future GDP, while the remaining variables short run were not significant. The robustness of the model can be showed by coefficient of determination of the analysis called $\mathrm{R}^{2}$ with $0.832453(83.24 \%)$ which can determine the explanatory power of the exogenous variables on endogenous variable and also F-statistic showed the robustness and uniqueness of the model with 5.350667 value at $0.001838<0.05$ level of significant which means the whole was good enough.

The long run captured by $\mathrm{C}_{1}$ coefficient in the table above showed the relationship between real GDP and all the exogenous variables with a value of $0.122613(12.26 \%)$ and level of significant value $-3.0833>0.05$ and with negative value that proved the necessary and sufficient condition of long run relationship existence.

The Volatility in the stock of financial market and international market for crude oil price in respect to macroeconomic indicators can be predicted with General Autoregressive Conditional Heteroscedasticity (GARCH) Technique. The estimation technique used the dynamic least square method in estimating ARCH and GARCH $(1,1)$ model for the estimation of crude oil price with the degree of exchange rate volatility (i.e. external force) and estimation of financial stock with the degree of interest rate unstable (i.e. internal force). Where both ARCH and GARCH term are of the first order as stated in the parenthesis.

The model is stated below; 
$\phi t^{2}=\varnothing+\alpha p^{2}-1+\beta \gamma^{2}-1$

Where,

$\$ t^{2}=$ conditional variance

$\varnothing=$ constant term

$\mathrm{p}^{2} \mathrm{t}-1=$ the news about the volatility from previous period which is measured by the lag of the square residual from the mean equation (Arch term)

$\gamma^{2} \mathrm{t}-1=$ the last period forecast of variance of the Arch term

The decision rule after summing the root of the autoregressive model is stated thus;

If $\alpha+\beta$ is less than 0.5 , there is no volatility;

If $\alpha+\beta$ fall between 0.5 and 1 , there is volatility;

If $\alpha+\beta$ is greater than 1 , there is a case of overshooting volatility.

The result of the GARCH $(1,1)$ is presented in Table below;

Table 4: Test of Volatility through Exchange Rate and Interest Rate

GARCH $=\mathrm{C}(4)+\mathrm{C}(5)^{*} \mathrm{RESID}(-1)^{\wedge} 2+\mathrm{C}(6)^{*} \mathrm{GARCH}(-1)+\mathrm{C}(7)^{*} \mathrm{INTR}+\mathrm{C}(8)^{*}$ EXTR

\begin{tabular}{|c|c|c|c|c|}
\hline Variable & Coefficient & Std. Error & z-Statistic & Prob. \\
\hline UNEM & 61.67815 & 12.47682 & 4.943421 & 0.0000 \\
\hline COILP & 0.849543 & 0.755739 & 1.124123 & 0.2610 \\
\hline ASI & 0.010152 & 0.001129 & 8.991109 & 0.0000 \\
\hline \multicolumn{5}{|l|}{ Variance Equation } \\
\hline C & 6458.577 & 10184.50 & 0.634158 & 0.5260 \\
\hline $\operatorname{RESID}(-1)^{\wedge} 2$ & 0.197386 & 0.050828 & 3.883404 & 0.0310 \\
\hline GARCH(-1) & 0.563659 & 0.195302 & 2.886089 & 0.0356 \\
\hline INTR & -225.9702 & 50.11249 & -4.509259 & 0.0106 \\
\hline EXTR & -17.19367 & 5.16988 & -3.325737 & 0.0446 \\
\hline$\alpha+\beta$ & 0.761045 & & & \\
\hline R-squared & 0.718959 & \multicolumn{2}{|c|}{ Mean dependent var } & 533.9968 \\
\hline Adjusted R-squared & 0.698885 & \multicolumn{2}{|c|}{ S.D. dependent var } & 242.2618 \\
\hline S.E. of regression & 132.9386 & \multicolumn{2}{|c|}{ Akaike info criterion } & 12.12027 \\
\hline Sum squared resid & 494834.9 & \multicolumn{2}{|c|}{ Schwarz criterion } & 12.49033 \\
\hline Log likelihood & -179.8642 & \multicolumn{2}{|c|}{ Hannan-Quinn criter. } & 12.24090 \\
\hline Durbin-Watson stat & 0.405780 & & & \\
\hline
\end{tabular}

Source: Eview 9

$\$ t^{2}=6458.577+0.197386 p^{2} t-1+0.563659 \gamma^{2} t-1$

Following the rules stated above, the addition of the root of the coefficient of $\mathrm{ARCH}$ and GARCH $(\alpha+\beta)$ is 0.761045 which indicate that there is volatility in the economy through exchange rate and interest rate (external and internal) macroeconomic indicators on crude oil price and stock price. 
Now coming to variance equation table, the probability of $\operatorname{RESID}(-1)^{\wedge} 2[\mathrm{ARCH}$ Term] is equal to 0.0310 , that is $\mathrm{P}<0.05$, therefore volatility can be predicted by $\mathrm{ARCH}$ term as its probability is significant. However, the probability of the $\{\mathrm{GARCH}$ Term\} GARCH(-1) is equal to 0.0356 , that is $\mathrm{P}<0.05$, therefore $\mathrm{GARCH}$ term is significant to predict volatility in the model. Therefore, exchange rate and interest rate (external and internal) macroeconomic indicators on crude oil price and stock price exhibits a degree of volatility clustering since GARCH is statistically significant.

Now, significance of the whole model with the help of $R^{2}$. The values of $R^{2}$ is equal to $0.718959(71.89 \%)$, this means that this model is healthy.

\section{Empirical Analysis and Discussion}

Preliminary diagnostics of the data in terms of descriptive statistics show that all the series record high standard deviations. The significant difference in terms of the means of the data make a case for using the natural logarithms of the data for estimation. In terms of symmetry, all the series exhibit a moderate positive skewness except unemployment that was found to have a long right tail. The positive kurtosis for the all the series indicates a relatively sharp distribution with that of exchange rate and interest rate being relatively flatter. For all the series, the null hypothesis of normality is accepted based on the Jarque-Bera statistic and probability value which was greater than 0.05 level of significance. The residual diagnostic check suggests that the shocks are white noise albeit notable structural breaks in the series which, coincide with the economic slowdown and policy change episodes in ours people.

The histogram normality test graph is presented below to show symmetric solidification of model structure for the analysis.

Figure 1: Normality test graph

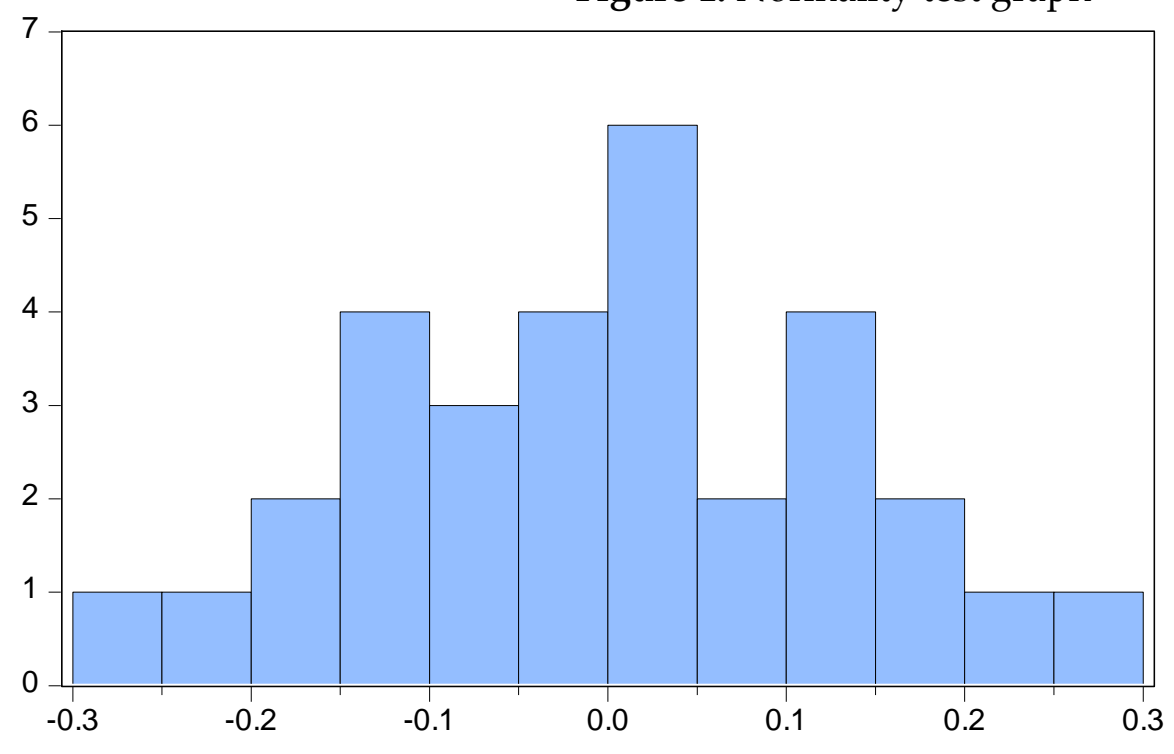

Series: Residuals

Sample 19862016

Observations 31

Mean

Median

$-7.59 \mathrm{e}-16$

Maximum

Minimum

Std. Dev.

Skewness

Kurtosis

0.001470

0.250404

$-0.276410$

0.130268

$-0.058593$

2.410577

Jarque-Bera $\quad 0.466489$

Probability $\quad 0.791960$ 
The probability value showed that all the variables were normally distributed by way of 0.791960 greater than 0.05 level of significance $(0.791960>0.05)$.

\section{Summary and Conclusion}

The attention of this journal was to analyse and forecast Crude Oil Price, Stock Price and Some Selected Macroeconomic Indicators with and Implication on the Growth of Nigeria Economy with emphasis on real GDP through crude oil price and all share index. This issue has generated substantial concern in view of its implications for macroeconomic and capital market unpredictability. The empirical analysis carried out relies on yearly data between 1986 and 2016 using the restructure neoclassical model. Findings reveal that the VECM and GARCH model predicted macroeconomic fundamentals quite well and this were validated by the co-integrating long run relationship vectors of the variables involved and the volatility captured by the Garch model that can be resolved with sound fiscal and monetary policies by government. It was observed that the exchange rate pass-through to crude oil price was significant in the build-up to the 2012 to 2016 recession and perhaps the policy response lags may have course for the longer recessionary period in the last quarter of 2016to first quarter 2017 and slow recovery, so also, interest rate run through to stock price that affect stock market which can bring crowd-out effect into private investment.

Conclusively, the study provides analytical insight on the modeling of macroeconomic volatility in Nigeria from oil price and stock price. The research evaluates the plausibility of symmetric and irregular volatility models and investigates the impact of oil price volatility stock price volatility on the volatility of four major macroeconomic variables (real GDP, exchange rate and interest rate and unemployment). The findings of the study reveal that there was inverse relationship between the macroeconomic variables with which not control with expansionary fiscal and monetary policies will lead to more economy challenges that can expand and bring more economy recession, meaning that the negative effects of exchange rate and interest rate effect the Nigerian economy in the modeling the volatility in the country. Oil price volatility also plays a significant role in the determination of the macroeconomic volatility. By implication, the Nigerian economy is vulnerable to both internal shocks and external shocks coursed by exchange rate and interest rate. Since the oil price volatility significantly impacts on the volatility of all the variables considered, it is a major source of macroeconomic volatility in Nigeria. Hence, fluctuations in oil price bring about instabilities in the Nigerian economy.

Although different models fit different environments, the study recommends that more credence may be given to Vector Autoregressive Error Correction Mechanism (VECM) for modeling macroeconomic volatility in Nigeria. Oil price may be considered as relevant variable in the analysis of macroeconomic fluctuations in Nigeria. Therefore, the Nigerian economy may be diversified by revamping other sectors such as the 
agricultural sector and the industrial sector in order to reduce overdependence on the oil sector which exchange rate volatility crowd-out in the economy in Nigeria.

\section{Conflict of Interest Statement}

The authors declare no conflicts of interests.

\section{About the Author}

Olanitori Idowu Paul is a Researcher, Analyst and an Economenrian at Paul Consult, Research and Data Analysis at Rufus Giwa Polytechnic Owo, Ondo State, Nigeria since 2015 till date. He barged Bachelor (B.Sc.) in Economics and Statistics at University of Benin, Benin City, Edo State. Current and former research interests are in the fields of Econometrics and Public Sector Economics.

Ademulegun Olaiya Hawley is a Lecturer at Rufus Giwa Polytechnic Owo, Ondo State, Nigeria since 2001 till date. He barged Master (M.Sc) in Economics at Ambrose Alli University, Ekpoma, Edo State. Current and former research interests are in the fields of Developmental Economics, Human Resource Management and Entrepreneurship Development.

Adeparubi Olateru-Olagbegi is a Lecturer at Rufus Giwa Polytechnic Owo, Ondo State, Nigeria since 2012 till date. She barged Master (M.Sc) in Accounting at University of Benin, Benin City. Current and former research interests are in the fields of Public Sector Accounting and Managerial Accounting.

\section{References}

Adeniyi (2011). Oil Price Shocks and Nigeria's Economic Activity: Evidence from ARDL Co-integration and VECM Analysis. Research Gate Research, July 2015.

Apere and Ijomah (2013). Oil Price Volatility and Economic Growth in Nigeria: An Empirical Investigation. European Journal of Humanities and Social Sciences Vol. 34, No.1, 2015

Ayadi et al. (2000). Macroeconomic Impact of Oil Price Levels and Volatility in Nigeria. International Journal of Academic Research in Economics and Management Sciences 2(4), 15-25.

Azeez, Kolapo, and Ajayi (2012). Effects of oil price changes on the sector indices of Istanbul stock exchange. International Research Journal of Finance and Economics, 25(2): 209-216.

Bernanke et al. (2007). Oil price volatility and US macroeconomic activity. Review, Federal Reserve Bank of St. Louis 57 (6): 669-683.

Counado G. \& Perez de Garcia B. (2005). Statistics and Probability. A Focused on Hypotheses Testing. Third edition. Strokes Global Ventures Owerri, Imo State, Nigeria. 
Chen, V. (2009). Statistical analysis of Cointegration vectors. Journal of Economic Dynamics and Control, 12(1988): 231 -254.

Caruth J., Hooker H. \& Oswald R. (2006). Impact of oil price on international economy. Term Paper, International Economics Master Course, Center of Excellence for Science and Innovation Studies, KTU University.

Cashin et al (2000). The Impact of News, Oil Prices, and Global Market Developments on Russian Financial Markets, Economics of Transition, 13, 373-393.

Daniel J. (2007). Nigerian Federalism in Crisis. Critical Perspectives and Political Options, Programme on Ethnic and Federal Studies, Department of Political science, University of Ibadan.

Elijah and Festus (2008). "Pseudo-Federalism and the political Crisis of Revenue Allocation" in Aghaje, A. et al (Eds) Nigeria's Struggle for Democracy and Good Governance: A festschrift for Oyeleye Oyediran, University Press, Ibadan.

Gisser \& Goodwin, (2006).Oil Shocks and the Macroeconomy: The Role of Price Variability. Energy Journal, 16, 39-56.

Gronwald, H. (2008). Oil Shock and Economic Growth in Japan: A Nonlinear Approach. Energy Economics, 30, 2374-2390.

Hamilton H. \& Herrera A. (2004). The Relative Importance of foreign and domestic shocks to Output and prices in Mexico and Colombia, Weltwirtschaftliches Archive, vol. 133(3): 458-477

Herrera G. \& Pesavento, J. (2009). “Do We Really Know that Oil Caused the Great Stagflation? A Monetary Alternative" in NBER Macroeconomic Annual 2001, 16, B.S. Bernanke and K. Rogoff, eds. Cambridge, MA:MIT Press, pp. 137-183.

Hooker, (2006). “Energy Price Shocks, Aggregate Supply and Monetary Policy: The Theory and International Evidence" in K. Brunner and A.H. Meltzer (eds) Supply Shocks, Incentives and National Wealth, Canergie-Rochester Conference Series on Public Policy, 4:9- 93.

Hooker U. (2002). Oil Prices, Inflation and Interest Rates in a Structural Cointegrated VAR Model for the G-7 Countries, Energy Economics, 38, 856-888.

Hoover V. \& Perez O. (2004). 'Recursive and Sequential Tests of the Unit Root and TrendBreak Hypotheses: Theory and International Evidence', Journal of Business EEconomic Statistics, 10, 271-87.

Kilian Y. (2008). Oil Price Volatility and the Global Financial Crisis. Paper presented at 9th Global Conference on Business \& Economics, Cambridge University, UK.

Kim M. \& Loughani G. (2002). Does Volatility in Crude Oil Price Precipitate Macroeconomic Performance in Nigeria? International Journal of Energy Economics and Policy, 3(2), 143-152.

Mork H. (2004). Crude Oil Price, Stock Price and Some Selected Macroeconomic Indicators: Implications on the Growth of Nigeria Economy, Research Journal of Finance and Accounting, 3(2), 42-48. 
LeBlanc T. \& Chinn U. (2004). An Analysis of the Effect of Oil Price Shock and Exchange Rate Instability on Economic Growth in Nigeria. Scottish Journal of Arts, Social Sciences and Scientific Studies ISSN 20471278.

Lounani O. (2006). Oil Price Volatility and Economic Growth in Nigeria: An Empirical Investigation. European Journal of Humanities and Social Sciences Vol. 34, No.1, 2015

Keane V. \& Prasad D. (2006). Conditional Heteroscedasticity in asset returns: a new approach. Econometrica, 59, 347-370.

Olomola \& Adejumo (2006). Oil price volatility and economic development: Stylized evidence in Nigeria. Journal of Economics and International Finance, 6(6), 125-133

Oriakhi, D. E., \& Osaze, I. D. (2013). Oil Price Volatility and its Consequences on the Growth of the Nigerian Economy: An Examination (1970-2010). Asian Economic and Financial Review, 3(5), 683-702.

Taiwo, M., Abayomi, T. \& Damilare O. (2012). Crude Oil Price, Stock Price and Some Selected Macroeconomic Indicators: Implications on the Growth of Nigeria Economy, Research Journal of Finance and Accounting, 3(2), 42-48.

Wilson, A. David, U. Inyiama, O. \& Beatrice, E. (2014). Oil price volatility and economic development: Stylized evidence in Nigeria. Journal of Economics and International Finance, 6(6), 125-133. 
Creative Commons licensing terms

Authors will retain copyright to their published articles agreeing that a Creative Commons Attribution 4.0 International License (CC BY 4.0) terms will be applied to their work. Under the terms of this license, no permission is required from the author(s) or publisher for members of the community to copy, distribute, transmit or adapt the article content, providing a proper, prominent and unambiguous attribution to the authors in a manner that makes clear that the materials are being reused under permission of a Creative Commons License. Views, opinions and conclusions expressed in this research article are views, opinions and conclusions of the author(s). Open Access Publishing Group and European Journal of Economic and Financial Research shall not be responsible or answerable for any loss, damage or liability caused in relation to/arising out of conflict of interests, copyright violations and inappropriate or inaccurate use of any kind content related or integrated on the research work. All the published works are meeting the Open Access Publishing requirements and can be freely accessed, shared, modified, distributed and used in educational, commercial and non-commercial purposes under a Creative Commons Attribution 4.0 International License (CC BY 4.0). 